\title{
Solvent- and catalyst-free synthesis of 2-aryl(heteroaryl)-substituted benzothiazoles $\dagger$
}

\author{
Nazanin Sedaghat, Mohammad Reza Naimi-Jamal* and Javad Mokhtari
}

Research Laboratory of Green Organic Synthesis \& Polymers, Department of Chemistry, Iran, University of Science and Technology, P.O. Box 1684613114 Tehran, I. R. Iran

\begin{tabular}{l}
\hline C H R O N I C L E \\
\hline Article history: \\
Received January 22, 2014 \\
Received in revised form \\
February 02, 2014 \\
Accepted 15 February 2014 \\
Available online \\
18 February 2014 \\
\hline Keywords: \\
Benzothiazoles \\
Melt reaction \\
Green synthesis \\
2-Aminothiophenol \\
\hline
\end{tabular}

\author{
A B S T R A C T \\ The condensation of several aromatic/heteroaromatic aldehydes with 2-aminothiophenol under \\ melt reaction conditions afforded 2-arylbenzothiazoles under solvent-free conditions. The major \\ advantages of the present method are high yields, short reaction times, and eco-friendly \\ conditions.
}

\section{Introduction}

Benzothiazoles and their derivatives are a very important group of heterocyclic compounds, ${ }^{1}$ and are well known for their biological and pharmaceutical activities, such as antimicrobial, ${ }^{2}$ and antiglutamate/antiparkinsonism agents ${ }^{3}$. Some of benzothiazoles exhibit nanomolar inhibitory activity against a range of human breast, ovarian, colon and renal cancer cell lines. ${ }^{4}$ Also, they can be used in industry as antioxidants and vulcanization accelerators that highlight their synthesis necessity. ${ }^{5}$ Benzothiazoles have been synthesized by different methods, such as condensation of 2aminothiophenol with carboxylic acid derivatives, ${ }^{6}$ base induced cyclization of corresponding 2haloanilides, ${ }^{7}$ or radical cyclization of thioacylbenzanilides. ${ }^{8}$ Some other methods include microwave-mediated reaction of 2-aminothiophenol with aldehydes in presences of $\mathrm{SiO}_{2}, \mathrm{Na}_{2} \mathrm{~S}_{2} \mathrm{O}_{5}$ as a catalyst, ${ }^{9}$ palladium-catalyzed Suzuki biaryl coupling of 2-halobenzothiazoles with arylboronic acids, ${ }^{10,11}$ coupling of benzothiazoles with aryl bromides ${ }^{12}$, the reaction between thiophenols and aromatic nitriles, ${ }^{13}$ Copper nanoparticles on activated carbon catalyzed.

\footnotetext{
* Corresponding author. Tel. /Fax: (+) 9821-77240289

E-mail addresses: naimi@, iust.ac.ir (M. R. Naimi-Jamal)

${ }^{\dagger}$ This paper has been managed by Dr. Ali Maleki

C 2014 Growing Science Ltd. All rights reserved. doi: $10.5267 /$ j.ccl.2014.2.003
} 
However, most of these synthetic approaches suffer from some drawbacks such as harsh reaction conditions, lengthy procedures, and expensive catalysts, which may be harmful to the environment. Therefore, the introduction of some green methods to overcome these limitations is still an important challenge. The science of green chemistry is developed to meet the increasing demand of environmentally benign chemical processes. In this regard, we have recently developed the application of solvent-free solid-solid and melt reactions as efficient methods for organic preparations. ${ }^{14} \mathrm{We}$ wish to report here a facile, environmentally friendly and clean synthesis of 2 substituted benzothiazoles via the reaction of aromatic or hetero aromatic aldehydes with $o$ aminothiophenol without using any catalyst, and under solvent-free melt reaction conditions.

\section{Result and discussion}

The reaction of $1.0 \mathrm{mmol}$ of 2-aminothiophenol (1) with $1.0 \mathrm{mmol}$ of $p$-chlorobenzaldehyde (2a) was chosen as a model reaction (Scheme 1).

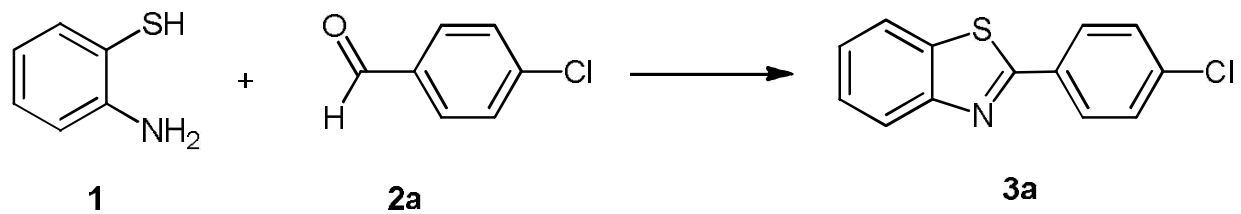

Scheme 1. Synthesis of 2-(4-chlorophenyl)benzo[d]thiazole as model reaction

The reaction mixture was grounded by a pestle in a mortar that afforded a doughy mixture. After 5 minutes grinding, the thin layer chromatography (TLC) of the reaction mixture (with hexane/ethyl acetate as eluent) has shown that the starting materials are still present. The reaction mixture became solid on further grinding, but the reaction was not complete, even after 1 hour. After heating the grounded mixture at $125^{\circ} \mathrm{C}$ in an ordinary oven, the product 3a was produced and the reaction was practically completed. By usual workup, the yield of the product 3a was determined as $81 \%$. Because of our previous successful works on using ball-milling in organic synthesis ${ }^{14}$, we also checked the model reaction by using a ball-mill apparatus. Although the reaction mixture became solid after 5 minutes grinding, but the starting materials did not disappeared even after 30 minutes grinding at room temperature. The model reaction was repeated as melt reaction. The starting materials were poured in a $10 \mathrm{~mL}$ round bottom flask and heated at $125^{\circ} \mathrm{C}$ in an ordinary oven. TLC showed that the reaction was completed after 1 hour. After crystallization in ethanol, $88 \%$ of pure 3a was afforded.

By using the melt method, various aromatic and heteroaromatic aldehydes reacted with 2aminothiophenol to produce the corresponding 2-arylbenzothiazoles with no need to any catalyst. Irrespective of the presence of electron withdrawing or releasing substituents in the ortho-, meta-, or para positions, the reactions proceeded fairly well and afforded the desired products in good to excellent yields (3a-k, Table 1). Heteroaromatic aldehydes needed higher temperatures, but they also afforded the corresponding 2-heteroaryl benzothiazoles with up to 97\% yields (Table 1, entries $\mathbf{3 h}-\mathbf{k}$ ).

Two possible mechanisms of the reaction were shown in Scheme 2. Both of the mechanisms proceed via a 2,3-dihydrobenzo[d]thiazole intermediate (4) which will transform to 3 by an oxidation reaction. Although we could not prove whether the reaction starts with the nucleophilic attack of the nitrogen- or sulphur atom of $\mathbf{1}$ to the carbonyl group in $\mathbf{2}$, the presence of the intermediate $\mathbf{4}$ was proved by the analysis of the reaction mixture of 2-aminothiophenol (1) with $1.0 \mathrm{mmol}$ of $p$ bromobenzaldehyde ( $2, \mathrm{R}=4$-bromo). The reaction mixture was grounded by a pestle in a mortar. After 5 minutes grinding, the thin layer chromatography (TLC) of the reaction mixture (with hexane/ethyl acetate as eluent) has shown 3 points, which belonged to the starting materials along with a new material. After careful isolation of this product by plate chromatography and recording its FT-IR spectrum, the absorbance peak at $3432 \mathrm{~cm}^{-1}$ of NH has proved the presence of the intermediate 4. By heating the reaction mixture in air, the intermediate 4 was oxidized to 3 . Obviously no further oxidizing agent, except than air was needed. This is in contrast to the previously published methods, 
which used the presence of an extra oxidant. ${ }^{16 c-f}$ In order to prove the aerobic oxidation, we repeated the reaction of 4-bromobenzaldehyde and 2-aminothiophenol in a similar experiment in the absence of air. After heating the reaction mixture in vacuum, at $125^{\circ} \mathrm{C}$ for 150 minutes, no benzothiazole product 3 was observed.

Table 1. Direct synthesis of 2-aryl benzothiazoles

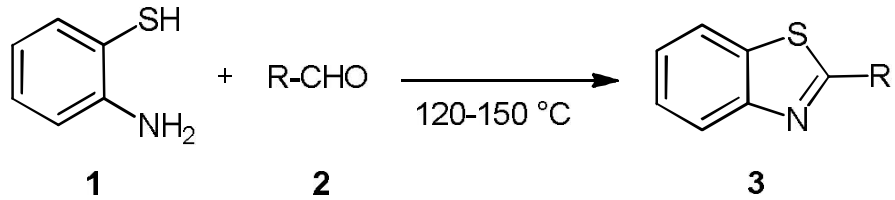

\begin{tabular}{|c|c|c|c|c|c|c|}
\hline Entry & $\mathrm{R}$ & Temp. ( $\left.{ }^{\circ} \mathrm{C}\right)$ & Time (min) & Product & m.p. (lit) ${ }^{15,16}$ & Yield (\%) \\
\hline 1 & $4-\mathrm{ClC}_{6} \mathrm{H}_{4}$ & 125 & 60 & $\mathbf{3 a}$ & $116-117(117-118)$ & 88 \\
\hline 2 & $4-\mathrm{BrC}_{6} \mathrm{H}_{4}$ & 125 & 60 & $3 \mathbf{b}$ & $130-132(133-134)$ & 97 \\
\hline 3 & $4-\mathrm{MeOC}_{6} \mathrm{H}_{4}$ & 125 & 60 & $3 c$ & $120-122(121-122)$ & 82 \\
\hline 4 & $4-\mathrm{CNC}_{6} \mathrm{H}_{4}$ & 125 & 75 & 3d & $159-161(162)$ & 83 \\
\hline 5 & $4-\mathrm{NO}_{2} \mathrm{C}_{6} \mathrm{H}_{4}$ & 125 & 60 & $3 e$ & $226-228(229-230)$ & 81 \\
\hline 6 & $2-\mathrm{OHC}_{6} \mathrm{H}_{4}$ & 150 & 90 & $3 f$ & $130-132(131-132)$ & 85 \\
\hline 7 & $3-\mathrm{NO}_{2} \mathrm{C}_{6} \mathrm{H}_{4}$ & 125 & 60 & $3 g$ & $184-188(185-186)$ & 95 \\
\hline 8 & 2-pyridyl & 150 & 90 & $3 \mathrm{~h}$ & $135-136(134-135)$ & 97 \\
\hline 9 & 4-pyridyl & 150 & 90 & $3 \mathbf{i}$ & $131-133(134-135)$ & 73 \\
\hline 10 & 2-thiophyl & 150 & 90 & $3 \mathbf{j}$ & $95-97$ (99) & 76 \\
\hline 11 & 2-furfuryl & 150 & 90 & $3 \mathbf{k}$ & $98-100(103-104)$ & 82 \\
\hline 12 & $i$-Bu & 125 & 30 & $*$ & - & - \\
\hline
\end{tabular}

Mechanism A:

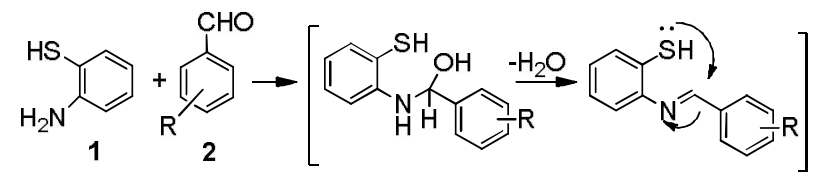<smiles>[R]#CCC1c2ccccc2NC1c1ccccc1</smiles>

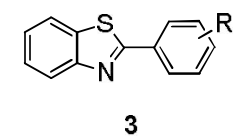

\section{Mechanism B:}
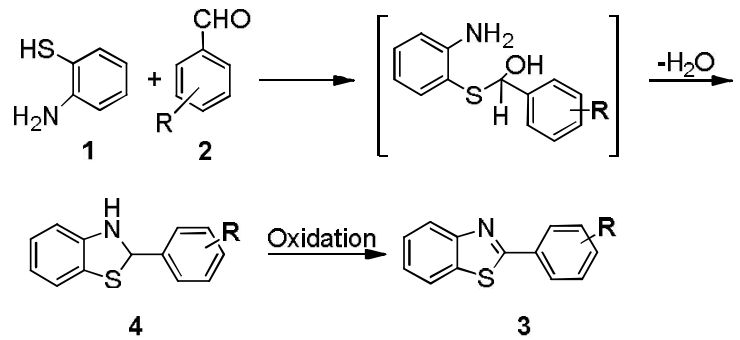

Scheme 2. Two possible mechanism of benzothiazole preparation

Unexpectedly, the reaction of alkyl aldehydes such as isobutyraldehyde did not afford the corresponding benzothiazoles 3 (Table 1, Entry 12). The melt reaction of $1.0 \mathrm{mmol}$ isobutyraldehyde 21 with $1.0 \mathrm{mmol}$ of $\mathbf{1}$, after $30 \mathrm{~min}$ heating at $125^{\circ} \mathrm{C}$ afforded 2,3-dihydro-2isopropylbenzo[d]thiazole (5) as the sole product (Scheme 3). The structure of the compound 5 was confirmed by ${ }^{1} \mathrm{H}-\mathrm{NMR}$ spectrum (Fig. 1). The doublet at $5.2 \mathrm{ppm}$ (with ${ }^{3} \mathrm{~J}=6.3 \mathrm{~Hz}$ ) belongs to the 2$\mathrm{H}$ in the thiazole ring and the broad signal at $4.2 \mathrm{ppm}$ belongs to the NH. Other aliphatic aldehydes also showed similar results. This result is especially interesting, because similar methods have reported the formation of the corresponding benzothiazoles 3 in the reaction of aliphatic aldehydes, although with low yields. ${ }^{15 a}$ To the best of our knowledge, none of similar methods reported on preparation of $\mathbf{5}$.

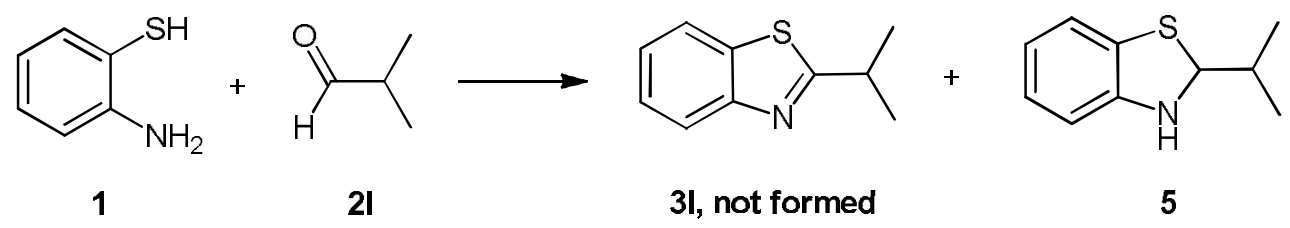

Scheme 3. The reaction of $1.0 \mathrm{mmol}$ of 2-aminothiophenol (1) with $1.0 \mathrm{mmol}$ of isobutyraldehyde (2l) 


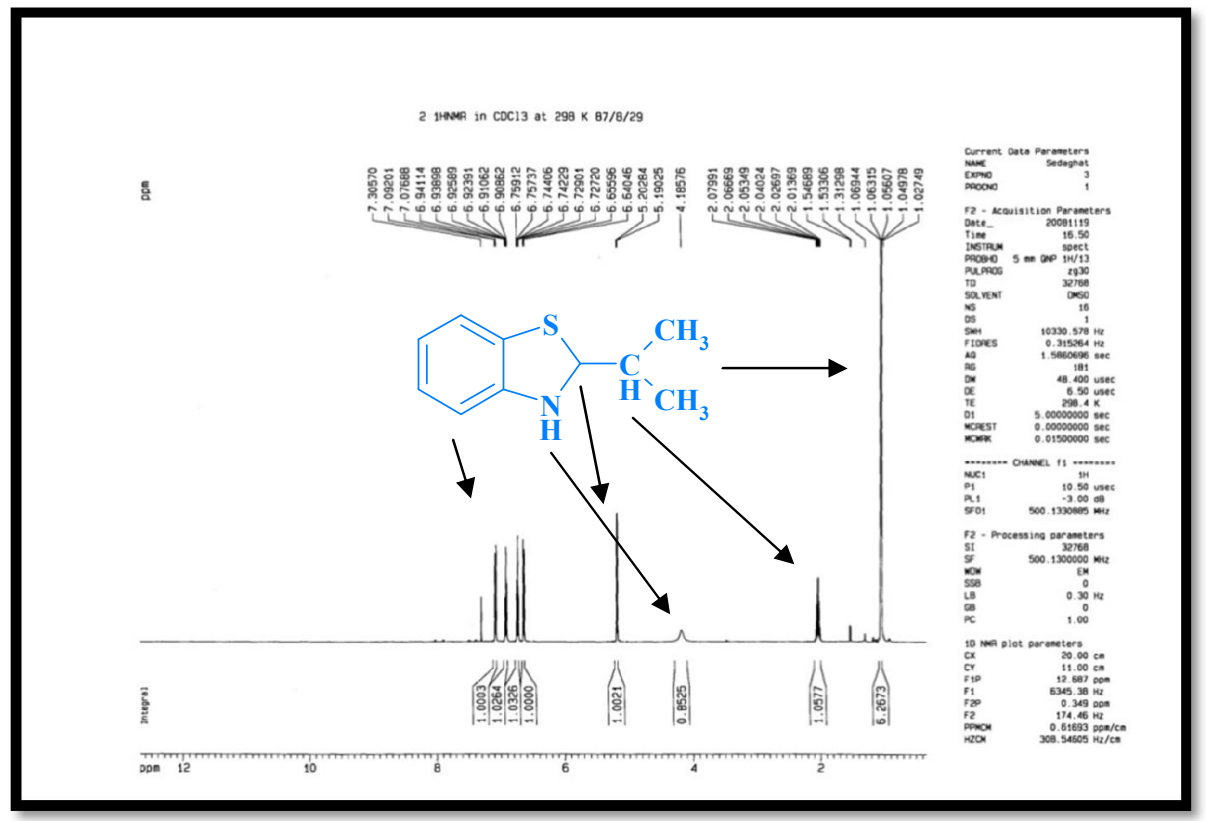

Fig. 1. ${ }^{1} \mathrm{H}-\mathrm{NMR}$ spectrum of compound 5

\section{Conclusion}

In conclusion, the melt reaction in air was found to be an efficient method for the preparation of 2-aryl/heteroaryl benzothiazoles via the reaction of 2-aminothiophenol with substituted aryl/heteroaryl aldehydes, in good to excellent yields. The advantages of the present synthetic protocol are solvent-free conditions, eco-friendly and easy reaction work-up procedure with no need to a catalyst. Among these, the most important feature of this work is no need to an extra oxidizing agent, except than air. By using aliphatic aldehydes or performing the reaction in vacuum, 2,3dihydrobenzo[d]thiazoles were prepared. The sustainability of this environmentally friendly technique may be compared to some previous techniques in Table 2. These methods are much more complicated, less atom-economic, and afford lower yields under severe conditions and longer reaction times (Table 2).

Table 2. Comparison of different synthesis method for 2-aryl benzothiazoles

\begin{tabular}{lc}
\hline Reactions Condition & Yield (\%) \\
\hline Melt condition (present work) & $81-97$ \\
$\mathrm{P}_{2} \mathrm{O}_{5}, \mathrm{CH}_{3} \mathrm{SO}_{3} \mathrm{H}, \Delta, 10 \mathrm{~h}^{16 \mathrm{a}}$ & $74-96$ \\
$\mathrm{n}-\mathrm{BuLi}, \mathrm{THF},-80^{\circ} \mathrm{C}^{16 \mathrm{~b}}$ & $41-81$ \\
$\mathrm{CAN}, \mathrm{NaHCO}{ }_{3}, \mathrm{MeCN}, 30 \mathrm{~min}^{16 \mathrm{c}}$ & $78-96$ \\
$p$-TsOH, MW & $52-85$ \\
$\mathrm{Pd}_{2}(\mathrm{dba})_{3}, \mathrm{DME}-\mathrm{Water}, \mathrm{K}_{2} \mathrm{CO}_{3}, 100^{\circ} \mathrm{C}, 6 \mathrm{~h}^{16 \mathrm{e}}$ & $48-72$ \\
$\mathrm{O}_{2}, \mathrm{Xylene}^{16} 50^{\circ} \mathrm{C}^{16 \mathrm{f}}$ & $72-86$ \\
$\mathrm{DDQ}, \mathrm{CH}_{2} \mathrm{Cl}_{2}, \mathrm{RT}, 20 \min ^{16 \mathrm{~g}}$ & $83-95$ \\
\hline
\end{tabular}

\section{Experimental Section}

\subsection{Materials and methods}

Melting points were measured on an Electrothermal 9100 apparatus. IR spectra were recorded on 
a Shimadzu IR-460 spectrometer. Mass spectra were recorded on a FINNIGAN-MAT 8430 mass spectrometer operating at an ionization potential of $70 \mathrm{eV} .{ }^{1} \mathrm{H}$ and ${ }^{13} \mathrm{C}$ NMR spectra were recorded at 500 and $125 \mathrm{MHz}$, respectively, on a BRUKER DRX 500-AVANCE FT-NMR instrument with $\mathrm{CDCl}_{3}$ as solvent. The reagents and solvents used in this work were obtained from Fluka (Buchs, Switzerland), or Merck and used without further purification.

\subsection{General procedure for the preparation of benzothiazoles $\mathbf{3}$, exemplified on $\mathbf{3 b}$ :}

A mixture of $1.0 \mathrm{mmol}$ of 2-aminothiophenole (1) and $1.0 \mathrm{mmol}$ of 4-bromobenzaldehyde (2a) was heated in a $10 \mathrm{~mL}$ round bottom flask in an ordinary oven at $125^{\circ} \mathrm{C}$ for 60 minutes to afford the crude product $(\mathbf{3 b})$. The progress of the reaction was monitored by TLC. Further purification was recrystallization from $96 \%$ ethanol.

\section{Representative spectral data:}

2-(4-Bromophenyl)benzo[d]thiazole $(3 \mathrm{~b})$ : White powder, $\mathrm{mp}=130-132{ }^{\circ} \mathrm{C}$, yield $97 \%$. IR $(\mathrm{KBr})$ $\left(v_{\max }, \mathrm{cm}^{-1}\right): 3000(\mathrm{CH}), 1400-1600(\mathrm{Ar}) .{ }^{1} \mathrm{H} \mathrm{NMR}\left(500.13 \mathrm{MHz}, \mathrm{CDCl}_{3}\right): \delta_{\mathrm{H}}=7.44\left(1 \mathrm{H}, \mathrm{t},{ }^{3} J_{\mathrm{HH}}=8.0\right.$ $\mathrm{Hz}, \mathrm{CH}$ of Ar), $7.55\left(1 \mathrm{H}, \mathrm{t},{ }^{3} \mathrm{~J}_{\mathrm{HH}}=8.0 \mathrm{~Hz}, \mathrm{CH}\right.$ of Ar$), 7.67\left(2 \mathrm{H}, \mathrm{d},{ }^{3} J_{\mathrm{HH}}=8.5 \mathrm{~Hz}, 2 \mathrm{CH}\right.$ of Ar$), 7.94$ $\left(1 \mathrm{H}, \mathrm{d},{ }^{3} J_{\mathrm{HH}}=8.0 \mathrm{~Hz}, \mathrm{CH}\right.$ of Ar$), 8.0\left(2 \mathrm{H}, \mathrm{d},{ }^{3} J_{\mathrm{HH}}=8.5 \mathrm{~Hz}, 2 \mathrm{CH}\right.$ of Ar$), 8.11\left(1 \mathrm{H}, \mathrm{d},{ }^{3} J_{\mathrm{HH}}=8.0 \mathrm{~Hz}\right.$, $\mathrm{CH}$ of $\mathrm{Ar}) .{ }^{13} \mathrm{C}$ NMR $\left(125.75 \mathrm{MHz}, \mathrm{CDCl}_{3}\right): \delta_{\mathrm{C}}=122.01(\mathrm{CH}$ of $\mathrm{Ar}), 123.76(\mathrm{CH}$ of $\mathrm{Ar}), 125.85(\mathrm{C}-$ $\mathrm{N}), 125.87$ ( $\mathrm{CH}$ of $\mathrm{Ar}), 126.93$ ( $\mathrm{CH}$ of $\mathrm{Ar}), 129.34$ (2CH of $\mathrm{Ar}), 132.66$ (2CH of Ar), $133.00\left(\mathrm{C}_{i p s o}\right)$, $135.48\left(\mathrm{C}_{i p s o}\right), 154.52\left(\mathrm{C}_{i p s o}\right), 167.11\left(\mathrm{C}_{i p s o}\right)$.

2-(Pyridin-2-yl)benzo[d]thiazole (3h): White powder, $\mathrm{mp}=135-136{ }^{\circ} \mathrm{C}$, yield $97 \%$. IR $(\mathrm{KBr})\left(v_{\max }\right.$, $\left.\mathrm{cm}^{-1}\right): 3053(\mathrm{CH}), 1405-1600(\mathrm{Ar}) .{ }^{1} \mathrm{H}$ NMR $\left(500.13 \mathrm{MHz}, \mathrm{CDCl}_{3}\right): \delta_{\mathrm{H}}=7.38-7.41(1 \mathrm{H}, \mathrm{m}, \mathrm{CH}$ of pyridine), $7.45\left(1 \mathrm{H}, \mathrm{t},{ }^{3} J_{\mathrm{HH}}=8.0 \mathrm{~Hz}, \mathrm{CH}\right.$ of $\left.\mathrm{Ar}\right), 7.53\left(1 \mathrm{H}, \mathrm{t},{ }^{3} J_{\mathrm{HH}}=8.0 \mathrm{~Hz}, \mathrm{CH}\right.$ of Ar$), 7.86(1 \mathrm{H}, \mathrm{t}$, ${ }^{3} J_{\mathrm{HH}}=7.7 \mathrm{~Hz}, \mathrm{CH}$ of pyridine $), 7.98\left(1 \mathrm{H}, \mathrm{d},{ }^{3} J_{\mathrm{HH}}=8.0 \mathrm{~Hz}, \mathrm{CH}\right.$ of $\left.\mathrm{Ar}\right), 8.13\left(1 \mathrm{H}, \mathrm{d},{ }^{3} J_{\mathrm{HH}}=8.1 \mathrm{~Hz}\right.$, $\mathrm{CH}$ of pyridine), $8.40\left(1 \mathrm{H}, \mathrm{d},{ }^{3} \mathrm{~J}_{\mathrm{HH}}=8.0 \mathrm{~Hz}, \mathrm{CH}\right.$ of $\left.\mathrm{Ar}\right), 8.70\left(1 \mathrm{H}, \mathrm{d},{ }^{3} J_{\mathrm{HH}}=4.7 \mathrm{~Hz}, \mathrm{CH}\right.$ of pyridine $)$. ${ }^{13} \mathrm{C}$ NMR $\left(125.75 \mathrm{MHz}, \mathrm{CDCl}_{3}\right): \delta_{\mathrm{C}}=121.19(\mathrm{CH}$ of pyridine), $122.44(\mathrm{CH}$ of $\mathrm{Ar}), 124.02(\mathrm{CH}$ of Ar), 125.67 ( $\mathrm{CH}$ of pyridine), 126.07 ( $\mathrm{CH}$ of $\mathrm{Ar}), 126.70(\mathrm{CH}$ of $\mathrm{Ar}), 136.58\left(\mathrm{C}_{\text {ipso }}\right), 137.41$ ( $\mathrm{CH}$ of $\mathrm{Ar}), 150.08$ (CH of pyridine), $151.85\left(\mathrm{C}_{i p s o}\right), 154.73\left(\mathrm{C}_{i p s o}\right), 169.80\left(\mathrm{C}_{i p s o}\right)$.

2-Isopropyl-2,3-dihydrobenzo[d]thiazole (5): liquid, yield: $85 \%$. ${ }^{1} \mathrm{H}$ NMR $\left(500.13 \mathrm{MHz}, \mathrm{CDCl}_{3}\right)$ : $\delta_{\mathrm{H}}=1.05\left(6 \mathrm{H}, \mathrm{d},{ }^{3} J_{\mathrm{HH}}=6.7 \mathrm{~Hz}, \mathrm{CH}_{3}\right), 2.05\left(1 \mathrm{H}\right.$, hep., $\left.{ }^{3} J_{\mathrm{HH}}=6.7 \mathrm{~Hz}, \mathrm{CH}\right), 4.18(1 \mathrm{H}, \mathrm{bs}, \mathrm{NH}), 5.19$ $\left(1 \mathrm{H}, \mathrm{d},{ }^{3} J_{\mathrm{HH}}=6.3 \mathrm{~Hz}, \mathrm{CH}\right), 6.64\left(1 \mathrm{H}, \mathrm{d},{ }^{3} J_{\mathrm{HH}}=7.7 \mathrm{~Hz}, \mathrm{CH}\right.$ of Ar$), 6.74\left(1 \mathrm{H}, \mathrm{t},{ }^{3} J_{\mathrm{HH}}=7.5 \mathrm{~Hz}, \mathrm{CH}\right.$ of Ar), $6.92\left(1 \mathrm{H}, \mathrm{t},{ }^{3} J_{\mathrm{HH}}=7.7 \mathrm{~Hz}, \mathrm{CH}\right.$ of $\left.\mathrm{Ar}\right), 7.08\left(1 \mathrm{H}, \mathrm{d},{ }^{3} J_{\mathrm{HH}}=7.5 \mathrm{~Hz}, \mathrm{CH}\right.$ of Ar$)$.

\section{Supplementary data}

Supplementary data are available under: http://www.growingscience.com/ccl/Vol3/ccl_2014_5_s.pdf

\section{Acknowledgements}

We acknowledge Iran University of Science and Technology (IUST) for partial financial support of this work. We thank Dr. Shahrzad Javanshir for her advices. Our special gratitude goes to Professor Abdol Jalil Mostashari for his helpful discussions.

\section{References}

1. Horton D.A., Bourne, G.T., Smythe, M.L. (2003) The combinatorial synthesis of bicyclic privileged structures or privileged substructures. Chem. Rev., 103, 893-930. 
2. Palmer P.J., Trigg R.B., Warrington J.V. (1971) Benzothiazolines as antituberculous agents. J. Med. Chem., 14, 248-251.

3. Benazzouz A., Boraud T., Dubédat P., Boireau A., Stutzmann J.M., Gross C. (1995) Riluzole prevents MPTP-induced parkinsonism in the rhesus monkey: a pilot study, Eur. J. Pharmacol., 284, 299-307.

4. Bénéteau V., Besson T., Guillard J., Léonce S., Pfeiffer B. (1999) Synthesis and in vitro antitumour evaluation of benzothiazole-2-carbonitrile derivatives. Eur. J. Med. Chem., 34, 1053-1060

5. Ivanov S.K., Yuritsyn V.S. (1971) Neftekhimiya, 11, 99-107.

6. Ben-Alloum A., Bakkas S., Soufiaoui M. (1997) Nouvelle voie de synthèse des 2-arylbenzothiazoles transfert d'electrons activé par micro-ondes. Tetrahedron Lett. 38, 6395-6396

7. Roe A., Tuker W.P. (1965) The preparation of some fluorobenzothiazoles. J. Heterocycl. Chem., 2, 148-151.

8. Hutchinson I., Stevens M.F.G., Westwell A.D. (2000) The regiospecific synthesis of 5- and 7monosubstituted and 5,6-disubstituted 2-arylbenzothiazoles, Tetrahedron Lett., 41, 425-428.

9. (a) Paul S., Gupta M., Gupta R. (2002) Microwave-induced solvent-free synthesis of 2arylbenzothiazoles using $p$-TsOH. Synth. Commun., 32, 3541-3547. (b) Weekes A.A., Dix M.C., Bagley M.C., Westwell A.D. (2010) Rapid and convenient thermal or microwave-assisted synthesis of substituted 2-phenylbenzothiazoles. Synth. Commun., 40, 3027-3032. (c) Mitsuo K., Tamaru Y., Aoyama T. (2004) Solvent-free synthesis of 2-aryl and 2-alkylbenzothiazoles on silica gel under microwave irradiation, Synth. Commun., 34, 3029-3036.

10. Majo V.J., Prabhakaran J., Mann J.J., Kumar J.S.D. (2003) An efficient palladium catalyzed synthesis of 2-arylbenzothiazoles, Tetrahedron Lett., 44, 8535-8537.

11. Heo Y., Song Y.S., Kim B.T., Heo J.N. (2006) A highly regioselective synthesis of 2-aryl-6chlorobenzothiazoles employing microwave-promoted Suzuki-Miyaura coupling reaction, Tetrahedron Lett., 47, 3091-3094.

12. Alagille D., Baldwin R.M., Tamagnan G.D. (2005) One-step synthesis of 2-arylbenzothiazole ('BTA') and -benzoxazole precursors for in vivo imaging of $\beta$-amyloid plaques. Tetrahedron Lett., 46, 13491351.

13. Tale R.H. (2002) Novel Synthesis of 2-Arylbenzothiazoles Mediated by Ceric Ammonium Nitrate (CAN). Org. Lett., 4, 1641-1642

14. (a) Mokhtari J., Naimi-Jamal M.R., Hamzeali H., Dekamin M.G., Kaupp G. (2009) Kneading ballmilling and stoichiometric melts for the quantitative derivatization of carbonyl compounds with gassolid recovery. ChemSusChem, 2, 248-254. (b) Kaupp G., Naimi-Jamal M.R., Schmeyers J. (2003) Solvent-free Knoevenagel condensations and Michael additions in the solid state and in the melt with quantitative yield. Tetrahedron, 59, 3753-3760. (c) Kaupp G., Naimi-Jamal M.R., Stepanenko V. (2003) Waste-free and facile solid-state protection of diamines, anthranilic acid, diols, and polyols with phenylboronic acid. Chem. Eur. J., 9, 4156-4160. (d) Mashkouri S., Naimi-Jamal M.R. (2009) Mechanochemical solvent-free and catalyst-free one-pot synthesis of pyrano[2,3-d]pyrimidine2,4(1H,3H)-diones with quantitative yields. Molecules, 14, 474-479. (e) Naimi-Jamal M.R., Mashkouri S., Sharifi A. (2010) An efficient, multicomponent approach for solvent-free synthesis of 2-amino-4Hchromene scaffold. Mol. Div., 14, 473-477.

15. (a) Kodomari M., Tamara Y., Aoyama T. (2004) Solvent-free synthesis of 2-aryl and 2alkylbenzothiazoles on silica gel under microwave irradiation. Synth. Commun., 34, 3029, (b) Fawzia A.Q., Mekheimer R.A., Sadek K.U. (2008) Cerium (IV) ammonium nitrate (CAN) catalyzed one-pot synthesis of 2-arylbenzothiazoles, Molecules, 13, 2908-2914.

16. (a) Boger L.A (1977) Convenient preparation of 2-substituted benzothiazoles. J. Org. Chem., 43, 11. (b) Stanetty P., Krumpak B. (1996) Novel synthesis of benzothiazole derivatives via directed lithiation and aryne-mediated cyclization followed by quenching with electrophiles. J. Org. Chem., 61, 51305133. (c) Tale R.H. (2002) Novel synthesis of 2-arylbenzothiazoles mediated by ceric ammonium nitrate (CAN). Org. Lett., 4, 1641-1642. (d) Dileep Kumar J.S., Mann J. (2003) An efficient palladium catalyzed synthesis of 2-arylbenzothiazoles, Tetrahedron Lett., 44, 8535-8537. (e) Weekes A.A., Dix M.C., Bagley M.C., Westwell A.D. (2010) Rapid and convenient thermal or Microwave-assisted synthesis of Substituted 2-phenylbenzothiazoles, Synth. Commun., 40, 3027-3032. (f) Hayashi M., Kawashita Y.A (2006) Simple synthesis of 2-arylbenzothiazoles and its application to palladiumcatalyzed Mizoroki-Heck reaction, Tetrahedron Lett., 47, 4231-4233. (g) Idrees M., Bose S.A. (2007) Convenient access to substituted benzothiazole scaffolds via intramolecular cyclization of thioformanilides, Tetrahedron Lett., 48, 669-672. 